\title{
Foot pain frequently associated with vitamin D deficiency: Bone marrow edema syndrome
}

\section{D vitamini eksikliği ile sıklıkla birliktelik gösteren bir ayak ağrısı nedeni: Kemik iliği ödemi sendromu}

\author{
Engin ECEViZ ${ }^{1 \oplus}$, Hüseyin Bilgehan ÇEViK ${ }^{1 \oplus}$, Özgür BAYSAL ${ }^{2}$, Güven BULUT ${ }^{1}$, Deniz GÜLABiं ${ }^{3}$, Gültekin Sıtkı ÇEÇEN ${ }^{3}$
}

\section{ABSTRACT}

\begin{abstract}
Aim: Bone marrow edema syndrome (BMES) describes nonspecific, ill-defined areas of hypo intense and hyper intense signal on $T 1$ and $T 2$ sequences, respectively. BMES has unknown etiology and resolves without sequel. In this study, we aimed to evaluate the initial clinical and radiological features and clinical course of patients with standing BMES.
\end{abstract}

Method: We evaluated 19 feet of 17 patients who applied to our clinic between January 2014 and December 2016. X-Ray and $M R I$ were taken in patients with clinical suspicion of BMES. Initial vitamin-D levels, hemogram, sedimentation, C-reactive protein (CRP), rheumatoid factor (RF) and Anti-CCP values of patients were evaluated. After the diagnosis, indomethacin and vitamin-D therapy and weight-bearing protection with double crutches was given for 6 weeks.

Result: All patients mentioned that sudden onset of pain. The mean duration of symptoms was 7.12(2-20) months. Mean serum 25(OH)D level was $14 \mathrm{IU}$, sedimentation values were slightly higher in 7 patients, CRP, RF and Anti-CCP values were normal. $B M E S$ mostly detected in talus. The mean AOFAS score of the patients was 63 and the last control was 92. Conservative treatments should be considered as the first-line treatment option in BMES.

Conclusion: The importance of laboratory tests in BMES should not be forgotten. Vitamin-D may play a role in the etiology of the disease. For that reason, patients need to be investigated in that way.

Keywords: Bone marrow edema, foot, ankle, vitamin D

\section{öz}

Amaç: Kemik iliği ödemi sendromu (KiÖs), etiyolojisi bilinmeyen, ani başlangıçlı ve kendini sınırlayıcı lokalize ağrıyla karakterize $M R$ görüntülemede sırasıyla T1 ve T2 sekanslarda hipointens ve hiperintens sinyal veren non-spesifik sekelsiz iyileşen kemik ödeminin gözlenmesidir. Bu çalışmada, ayakta KiöS tanılı hastaların başlangıç klinik ve radyolojik özellikleriyle klinik seyrinin değerlendirilmesi amaçlandı.

Yöntem: Kliniğimizde, Ocak 2014 ve Aralık 2016 arasında KiÖS tanısı alan 17 hasta çalışmaya dahil edildi. Ayak ağrısı yakınmasıyla başvuran klinik olarak KiÖS'den şüphelenilen hastalarda direkt grafi ve sonrasında MR görüntüleme istendi. KiÖS tanısı alan hastaların başlangıç D-vitamini, hemogram, sedimentasyon, C-reaktif protein (CRP), romatoid faktör (RF) ve Anti-CCP değerlerine bakıldı. Hastalara tanıdan itibaren indometazin ve D-vitamini başlandı, 6 hafta çift koltuk değneğiyle yükten koruma uygulandı.

Bulgular: Tüm hastaların öykülerinde ani başlangıçlı ayak ve ayak bilek ağrısı olduğu görüldü. Semptomların ortalama süresi 7,12 (2-20) aydı. Ortalama serum D vitamini düzeyi 14 IU olduğu, sedimentasyon değerlerinin 7 hastada hafif yüksek, $C R P, R F$ ve Anti-CCP değerlerinin normal olduğu gözlendi. KiÖS en fazla talusta görüldü. Hastaların tanı aldıklarındaki AOFAS skoru ortalama 63, son kontrol AOFAS skoru ortalama 92'ydi.

Sonuç: Konservatif tedaviler KiöS tanısı alan hastaların izlenmesinde ilk seçenek tedavi olarak değerlendirilmelidir. D-vitamini eksikliğinin hastalığın etiyolojisinde rol alabileceği bilinmeli ve bu yönde araştırılmalıdır.

Anahtar kelimeler: Kemik iliği ödemi, ayak, ayak bileği, D vitamini

Received: 17.05 .2018

Accepted: 04.10.2018

${ }^{1}$ Kartal Dr. Lütfi Kırdar Training and Research Hospital, Department of Orthopaedics and Traumatology, Istanbul, Turkey

${ }^{2}$ Marmara University Pendik Training and Research Hospital, Department of Orthopaedics and Traumatology, Istanbul, Turkey

${ }^{3}$ VM Medical Park Pendik Hospital, Department of Orthopaedics and Traumatology, Istanbul, Turkey

Corresponding author: Engin Eceviz, Kartal Dr. Lütfi Kırdar Training and Research Hospital, Department of Orthopaedics and Traumatology, Istanbul, Turkey

e-mail: bilgehancevik@gmail.com

ORCID ID's:

E.E. 0000-0003-2453-0869, H.B.Ç. 0000-0003-1945-3715 


\section{Giriş}

Kemik iliği ödemi sendromu (KiÖS) etiyolojisi bilinmeyen, ani başlangıçlı, kendi kendini sınırlayıc tarzda lokalize ağrı ile karakterize ve MR görüntülemede sırasıyla T1 ve T2 sekanslarda hipointens ve hiperintens sinyal veren non-spesifik sekelsiz iyileşen kemik ödeminin gözlenmesidir ${ }^{1,2}$. İlk defa 1959 yılında Curtis tarafından etkilenen kemiğin 6-8 hafta içinde direkt grafide osteoportik görünümü nedeniyle ilk olarak geçici osteoporoz olarak tanımlanmıştır ${ }^{3}$. Daha sonra Wilson tarafından bilgisayarlı tomografi ve histolojik incelemelerde osteoporoz olmaması ve magnetik rezonans görüntülemede karakteristik ödem benzeri sinyal vermesi nedeniyle geçici kemik iliği sendromu olarak tanımlanmıştır ${ }^{4}$.

Kalça, diz ve ayak bileğinden alınan histolojik örneklerin incelendiği bir çalışmada, yağ nekrozu olmaksızın ve aktif osteoblastların görüldüğü kemik iliği ödemi olduğu bildirilmiştir ${ }^{5}$. Aynı çalışmada, kansellöz kemikte trabekül incelmesi ve osteoklastik kemik rezorbsiyonu olduğundan söz edilmiştir. Kiös'ün etiyolojisi bilinmemektedir. Tromboembolizm, arterial veya venöz akımda obstrüksiyon, vaskülite sekonder damar duvarı zedelenmesi gibi intramedüller basınç artışı nedenleri ve bozulmuş lipid metabolizması, azalmış fibrinoliz, protein S eksikliği, sistemik osteoporoz, D vitamini eksikliği, C vitamini eksikliği, mikrotravma ve sigara etiyolojide suçlanmıştır ${ }^{6-9}$. Kadınlara göre erkeklerde 3 kat daha fazla görüldüğü bildirilmiştir ${ }^{6}$.

KiÖS iki ayrı şekilde sınıflandırılabilir. Birincisi, 3 temel yaygın mekanizmaya göre: grup 1 (iskemik), osteonekroz ve osteokondritis disekans ile ilişkili, grup 2 (mekanik), kemik kontüzyonu, mikrokırık, stres ile alakalı kemik iliği ödemi ve stres frakturleri ile ilişkili ve grup 3 (reaktif), osteoartrit, postoperatif ödem veya neoplaziler ile ilişkili, ${ }^{60-13}$. İkincisi ise, nedeni bilinmeyen primer kemik iliği ödemi (KiÖS) ve sekonder nedenlerin neden olduğu kemik iliği ödemidir. Bu sekonder nedenler travma, dejeneratif hastalıklar (osteoartrit), iskemik olaylar (orak hücreli anemi), inflamatuvar hastalıklar (inlamatuvar artrit), enfeksiyon (osteomyelit), neoplaziler (kemik tümörleri), metabolik hastalıklar (kronik böbrek yetmezliği), nörolojik hastalıklar (charcot artropatisi) veya iatrojenik nedenlerdir ${ }^{6,14}$.

KiÖS'ün ayırıcı tanısında; kemik kontüzyonu, stres kırığı, sudeck atrofisi, osteonekroz, diyabetik nöropati, enfeksiyon ve neoplazmlar bulunmaktadır.

KiÖS literatürde en sık proksimal femurda gözlenmekle birlikte diz çevresi ve ayak, ekstremitelerin diğer bölgelerine göre daha sıklıkla etkilenen bölgelerdir ${ }^{15}$.

Prevelansının az olması ve non-spesifik bulgularının olması nedeniyle ayak ve ayak bileğinde kiÖS tanısı genelde gecikmiş olarak konulur. Bu da hastanın ağrısının artmasına ve dolayısıyla yaşam kalitesinin bozulmasına neden olabilir.

Bu çalışmada, ayakta kemik iliği sendromu tanılı hastaların başlangıç klinik ve radyolojik özellikleri ile klinik seyrinin değerlendirilmesi amaçlandı.

\section{GEREÇ ve YÖNTEM}

Kliniğimize Ocak 2014 ve Aralık 2016 ayları arasında başvurup ayakta medüller ödem tanısı alan ve tedavi edilen 17 hasta çalışmaya dahil edildi. Kiös tanıSı MR'da T1 sekansta azalmış sinyal ve T2 sekansta artmış sinyal değişikliklerinin görülmesi ve olası diğer kemik iliği ödemi nedenlerinin dışlanmasıyla konuldu. KiÖS ayırıcı tanısında olan travmatik kemik kontüzyonları, osteokondritis dissekans, stres kırığı tanısı olan hastalar ile düzenli takiplere gelmeyen 2 hasta çalışmaya dahil edilmedi. Çalışmamız, hastanemizin Etik Kurulundan alınan 24.04.2018 tarih ve 2018/514/128/1 karar numarası ile kliniğimizde gerçekleştirilmiştir.

On yedi hastanın toplam 19 ayağı incelendi. Dokuz erkek, 8 kadından oluşan hasta grubunun yaş aralığı 16 ve 55 yaş arasında dağılmaktaydı. Ortalama takip süresi 16,2 (14-22) ay idi. Polikliniğimize ayak ağrıSı şikayeti ile başvuran klinik olarak medüller ödem sendromundan şüphelenilen hastalarda direkt grafi ve sonrasında şüphe üzerine $M R$ istendi. 
Ayakta KiÖS tanısı alan hastaların başlangıç D vitamini seviyelerine, hemogram, sedimentasyon, CRP, romatoid faktör ve Anti-CCP değerlerine bakıldı.

Çalışmaya katılan hastaların hepsi $D$ vitamini desteği almadıklarını bildirmiştir. Evrensel olarak 25(OH)D serum seviyelerine göre $D$ vitamini eksikliği ve yetersizliği ile ilgili bir kabul görmüş sınıflandırma bulunmamaktadır. Çalışmamızda, Türkiye Endokrinoloji ve Metabolizma Derneği tarafından yayınlanan Osteoporoz ve Metabolik Kemik Hastalıkları Tanı ve Tedavi Kılavuzu baz alınarak hastaların D vitamini seviyeleri değerlendirildi ${ }^{16}$. Kılavuza göre serum $25(\mathrm{OH}) \mathrm{D}$ seviyesi $\leq 20 \mathrm{ng} / \mathrm{mL}$ (50 nmol/L) D vitamini eksikliğini ve serum $25(\mathrm{OH}) \mathrm{D}$ seviyesi $21-29 \mathrm{ng} / \mathrm{mL}(52,5-72,5$ $\mathrm{nmol} / \mathrm{L})$ arasında ise $\mathrm{D}$ vitamini yetersizliğini göstermektedir. Serum 25(OH)D seviyesi $\geq 30 \mathrm{ng} / \mathrm{mL}$ (75 $\mathrm{nmol} / \mathrm{L}$ ) olması ise $\mathrm{D}$ vitamini seviyesinin yeterli olduğunu göstermektedir.

Tüm hastalar konservatif olarak tedavi edildi. Hastalara tanı aldıktan itibaren 6 hafta boyunca çift koltuk değneği ile yükten koruma uygulandı ayrıca indometazin (Endol kapsül, 25 mg, Deva İlaç, Türkiye) kapsül (2x1) ve D vitamini başlandı. D vitamini tedavisi Swiglo ve ark.'nın ${ }^{17}$ tedavi önerileri baz alınarak 8 hafta boyunca haftalık oral 50,000 IU vitamin D3 (Devit-3 ampül, 30,0000 IU/ml, Deva Illaç, Türkiye) ve idamede günlük oral 1,500-2,000 IU vitamin D3 (Devit-3 oral damla, 50,000 IU/15 ml, Deva İlaç, Türkiye) şemasında uygulandı. Hastalar klinik olarak AOFAS skorlaması ile değerlendirildi.

\section{BULGULAR}

Tüm hastaların öykülerinde ayak ve ayak bilek ağrısı yakınmasının ani başlangıçlı olduğu görüldü. Semptom başlangıcından başvuru anına kadar geçen süre ortalama 1,5 ay idi.

Hastaların ortalama başlangıç serum D vitamini düzeylerinin 14 IU olduğu, sedimentasyon değerlerinin 7 hastada hafif yüksek olduğu, CRP, RF ve Anti-CCP değerlerinin romatoid artrit tanılı iki hasta dışında normal olduğu gözlendi. Atkins ve ark.'nın ${ }^{18}$ belirttiği değerlere göre, 13 hastada vitamin $D$ eksikliği $(<20$ $\mathrm{ng} / \mathrm{mL}$ ) ve 4 hastada vitamin D yetersizliği (21-29 $\mathrm{ng} /$ $\mathrm{mL}$ ) görüldü. Hastalara Swiglo ve ark'nın ${ }^{17}$ tedavi önerileri baz alınarak 8 hafta boyunca haftalık 50000 IU vitamin D3 ve idamede günlük 1500-2000 IU vitamin D3 tedavisi uygulandı.

Tablo 1. Klinik bilgilerin özeti.

\begin{tabular}{|c|c|c|c|c|c|c|c|c|}
\hline Hasta & $\mathbf{Y}$ & C & Primer Etkilenen Kemik & Diğer Etkilenen Kemikler & $\begin{array}{l}\text { Semptom } \\
\text { Süresi (Ay) }\end{array}$ & $\begin{array}{l}\text { Yakınma ve başvuru } \\
\text { arasındaki süre (Ay) }\end{array}$ & $\begin{array}{l}\text { Başlangıç D vit. } \\
\text { (ng/mL) }\end{array}$ & $\begin{array}{l}\text { AOFAS ilk } \\
\text { ve son }\end{array}$ \\
\hline 1 & 17 & $E$ & Kalkaneus (L) & & 5 & 1 & 8,4 & $62 / 97$ \\
\hline 2 & 37 & $\mathrm{E}$ & Talus (R) & & 4 & 2 & 7,9 & $52 / 90$ \\
\hline 3 & 39 & $\mathrm{~K}$ & Talus (R) & Naviküla (R) & 8 & 3 & 7,4 & $62 / 95$ \\
\hline 4 & 46 & $E$ & Talus (L) & & 3 & 1 & 24,2 & $70 / 98$ \\
\hline 5 & 27 & $\mathrm{~K}$ & Küboid (L) & & 6 & 0 & 24,7 & 74 / 94 \\
\hline 6 & 27 & $E$ & Talus (R) & Lateral malleol (R) & 5 & 2 & 9,3 & 62 / 92 \\
\hline $7^{*}$ & 46 & $E$ & Median, medial ve lateral küneiform (R) & & 20 & 0 & 16,7 & $66 / 88$ \\
\hline 8 & 55 & $\mathrm{~K}$ & Median küneiform (R) & & 11 & 3 & 29 & $62 / 90$ \\
\hline 9 & 51 & $\mathrm{~K}$ & Talus (R) & & 4 & 1 & 7,1 & 66 / 92 \\
\hline 10 & 16 & $\mathrm{E}$ & Talus (L) & Kalkaneus (L) & 7 & 4 & 8,9 & 59 / 93 \\
\hline 11 & 18 & $E$ & Talus (R+L) & Kalkaneus (R+L) & 4 & 1 & 12 & $70 / 88$ \\
\hline 12 & 44 & K & 5. metatars $(R)$ & & 10 & 2 & 27 & 52 / 92 \\
\hline $13^{*}$ & 32 & $E$ & Talus (R) & Küboid, Naviküla (R) & 14 & 1 & 11,2 & 59 / 93 \\
\hline 14 & 52 & K & Küboid (L) & & 6 & 1 & 14,4 & 62 / 92 \\
\hline 15 & 29 & $\mathrm{E}$ & Naviküla (R) & & 4 & 1 & 17,1 & 74 / 94 \\
\hline 16 & 41 & $\mathrm{~K}$ & Kalkaneus (L) & & 3 & 3 & 9,5 & 66 / 92 \\
\hline 17 & 44 & $E$ & Talus (R) & Medial küneiform, Naviküla (L) & 7 & 0 & 9,2 & 59 / 93 \\
\hline Ort. & 36,5 & $10 \mathrm{E} / 7 \mathrm{~K}$ & & & 7,2 & 1,5 & 14,3 & 63 / 92 \\
\hline
\end{tabular}

Y: yaş, C: cinsiyet, * Romatoid artritli hastalar, E: erkek, K: kadın 
On bir ayakta tek kemik tutulumu, 6 ayakta 2 kemik ve 2 ayakta 3 kemik tutulumu gözlendi. Dokuz ayakta talus, 4 ayakta kalkaneus, 4 ayakta navikula, 3 ayakta küneiform, 3 ayakta küboid, 1 ayakta beşinci metatars ve 1 ayakta lateral malleol tutulumu saptandı.

Hastalarda mevcut semptomların ortalama süresi 7,12 (2-20) ay idi. Kontrollerde alınan direkt grafilerde hiçbir hastada osteonekroz başlangıcı görülmedi. Hastaların tanı aldıklarındaki AOFAS skoru ortalama 63 iken, semptomların geçmesinden sonraki ilk kontrolde AOFAS skoru ortalama 92 idi (Tablo 1 ).

\section{TARTIŞMA}

KiöS akut ayak ve ayak bilek ağrısının spontan başlangıçı ve geri dönüşümlü nadir nedenlerinden biridir. Literatürde insidansı hakkında bilgi bulunmamaktadır.

Bir çalışmada, kalçada Kiös'de kemik iliğinde yağ nekrozu gözlenmiş ${ }^{19}$, histopatolojik benzerlik nedeniyle avasküler nekrozun (AVN) erken aşaması olduğu ve hafif iskeminin başladığı bildirilmiştir ${ }^{20}$. Literatürde bir olguda kalçanın KiÖS'ünde takipte bir tarafta AVN geliştiği ve diğer tarafta ise spontan düzelme olduğu bildirilmiş, bunun da KiÖs'ün AVN'nin geri dönüşlü erken evresi ve her iki klinik durumun ortak patofizyolojik yolaklarının olduğu belirtilmiştir ${ }^{2,11}$. Bunlarla birlikte, KiÖS'ün AVN ile farklı hastalıklar olduğunu bildiren yayınlar da mevcuttur ${ }^{21,22}$. Ayrıca tromboembolizm, arteriyel veya venöz akımda obstrüksiyon, vaskülite sekonder damar duvarı zedelenmesi gibi intramedüller basınç artışı nedenleri ve bozulmuş lipid metabolizması, azalmış fibrinoliz, protein S eksikliği, sistemik osteoporoz, D vitamini eksikliği, C vitamini eksikliği, mikrotravma ve sigara etiyolojide suçlanmıştır ${ }^{7-9,23,24}$.

KiÖS'ün etiyolojisi bilinmemekle birlikte, hastalardan alınan kemik örneklerinin histolojik değerlendirmesinde yağ hücreleri destrüksiyonu, kemik sıvısında artış, düzensiz kemikler, dilate sinüsler, yeni kemik oluşumları ve fibrovasküler rekonstrüksiyonlar görülmüştür ${ }^{25,26}$. Yaşayan trabeküller ve aktif kemik oluşumu nedeniyle kemiğin onarım kapasitesi Kiös'ün spontan gerilemesinde primer etken olabilir ${ }^{26}$.

Ayakta KiÖS'de kullanılan tedavi modalitelerinin çoğu kalçada KiÖs'lerden elde edilmiştir. Fakat hiçbir tedavi seçeneği hastalığın olağan seyrini değiştirmemektedir ${ }^{2}$. Çalışmamızda bunun doğruluğunu gözlemledik. Literatürde yalnızca kor dekompresyonun semptomların süresini kısaltabileceği bildirilmiştir ${ }^{2,10}$. Singh ve ark. ${ }^{27}$ ayakta KiÖS hastalarının tedavilerinde bifosfonat kullanmışlar ve yararlı olabileceğini bildirmişlerdir. Aigner ve ark. ${ }^{18}$ ayakta KiÖS hastalarının tedavisinde damar dilatasyonu yapması, kapiller geçirgenliği azaltması ve oksijen radikallerinin ve lökotrienlerin azalmasını sağlayan prostosiklini kullanmışlar ve olumlu sonuçlar elde etmişlerdir.

Ayak ve ayak bileğinde Kiös'ün en sık talusta olduğu bildirilmiştir ${ }^{2,28}$. Yine çalışmamızda değerlendirilen 19 ayağın 9'unda talusta KiÖS saptanmıştır (Figür 1).

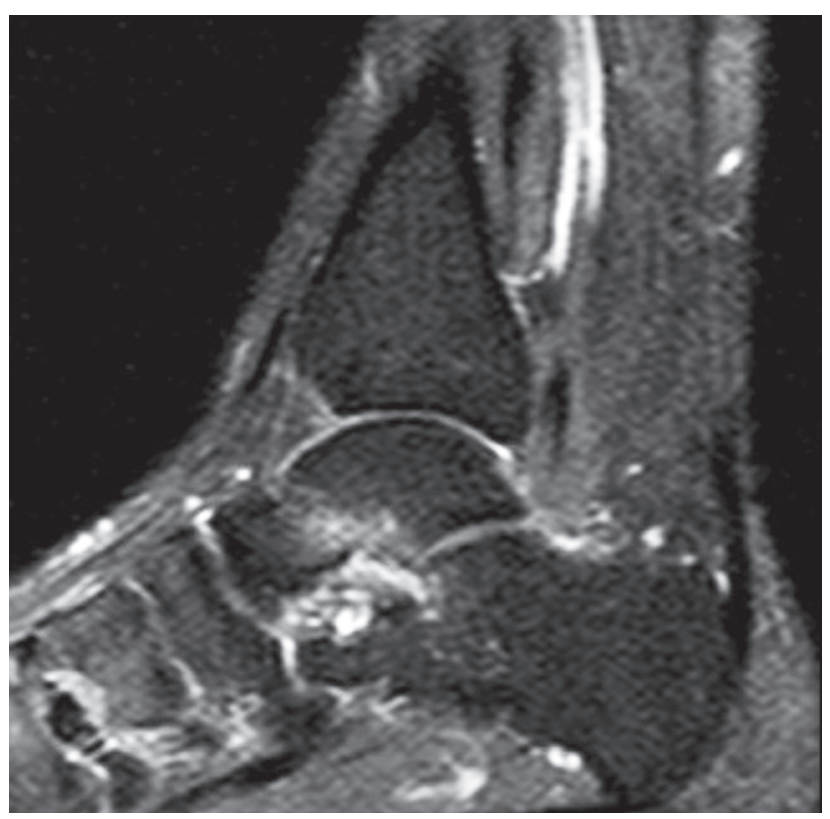

Figür 1. Talusta kemik iliği ödemi sendromu.

Literatürde kalçanın geçici KiÖs’ünde akut başlangıçIı aktiviteyle olan dinlenmeye geçen ağrı ve antaljik yürüyüş bildirilmiştir. Benzer yakınmalar bu çalışmadaki ayak ve ayak bilek KiÖS tanısı alan hastalarda da gözlendi. 
Türkiye'de D vitamini eksikliğinin sanıldığından daha fazla olduğu bildirilmiştir ${ }^{29-33}$. Hatta yeterli güneş ışığı olmasına rağmen, D vitamini eksikliğinin kapalı ortamlarda yaşamadan ve giyinme alışkanlığından olduğu belirtilmiştir ${ }^{30}$. Ingilizce literatürde ayakta KiÖS ve D vitamini ilişkisi ile ilgili iki yayın bulunmaktadır. Horas ve ark.'nın çalışmasında, 31 hastanın 26'sında D vitamini eksikliği saptanmıştır. Sprinchorn ve ark.'nın çalışmasında ise, 10 hastanın 9'unda D vitamini eksikliği olduğu bildirilmiştir. Bu çalışmadaki 17 hastanın 13'ünde D vitamini eksikliği, 4'ünde yetersizliği görülmüştür. Bir başka söylem ile tüm hastalarımızda $D$ vitamini seviyesi düşüktür. Literatür ve çalışmamızdaki sonuçlar doğrultusunda, KiÖS tanısı alan hastalarda D vitamini düzeyleri araştırılmalı ve $D$ vitamini eksiliği olması durumunda gerekli tedavi yapılmalıdır.

Tedavi verilmeksizin KiÖS'ün genelde 3-9 ay içerisinde iyileştiği belirtilmiştir ${ }^{8,22,34}$. Literatürde nonsteroidal antienflamatuvar tedavi, koltuk değneği ile yükten korumayı içeren konservatif tedaviler hastaların izlenmesinde ilk seçenek tedavi yöntemi olarak değerlendirilmesi önerilmiştir ${ }^{8,20,21,35}$. Literatürde konservatif tedaviye yanıt vermeyen hastalarda kor dekompresyon uygulanan çalışmalar bulunmaktadır ve kor dekompresyon ile mevcut semptomların süresinin kısalabileceği bildirilmiştir ${ }^{2,10,36}$. Bu çalışmadaki hastalara non-steroidal antiinflamatuvar tedavi ile birlikte koltuk değneği ile yükten korumayı içeren konservatif tedavi uygulandı ve hiçbirine cerrahi girişim gerekmedi.

Çalışmanın eksik yanları: retrospektif bir çalışma olması; tedavide NSAi tedavisi, yükten kurtarma ve D vitamini replasmanı gibi farklı yöntemlerin birlikte kullanılması, D vitamini seviyelerinde mevsimsel değişkenliğin değerlendirmeye alınmamasıdır.

\section{SONUÇLAR}

KiÖS spontan başlangıçlı geri dönüşlü bir hastalık olduğundan steroid olmayan antienflamatuvar ilaçlar ve koltuk değneği ile yükten yükten korumayı içeren konservatif tedaviler hastaların izlenmesinde ilk se- çenek tedavi yöntemi olarak değerlendirilmelidir.

KiÖS'de laboratuvar testlerinin önemi unutulmamalıdır. D vitamini eksikliğinin hastalığın etiyolojisinde rol alabileceği göz önünde bulundurulmalıdır. Bu nedenle hastaların bu yönde araştırılıp, D vitamini eksikliği olan hastalarda gerekli tedavinin düzenlenmesi gereklidir.

\section{KAYNAKLAR}

1. Orr JD, Sabesan V, Major N, Nunley J. Painful bone marrow edema syndrome of the foot and ankle. Foot \& Ankle International. 2010;31(11):949-53. https://doi.org/10.3113/FAl.2010.0949

2. Radke S, Vispo-Seara J, Walther M, Ettl V, Eulert J. Transient bone marrow oedema of the foot. International Orthopaedics. 2001;25(4):263-7. https://doi.org/10.1007/s002640100253

3. Curtiss PH, Kincaid WE. Transitory demineralization of the hip in pregnancy. JBJS Case Connector. 1959 (7):1327-33.

4. Wilson A, Murphy W, Hardy D, Totty W. Transient osteoporosis: transient bone marrow edema? Radiology. 1988;167(3):75760.

https://doi.org/10.1148/radiology.167.3.3363136

5. Naides S, Resnick D, Zvaifler N. Idiopathic regional osteoporosis: a clinical spectrum. The Journal of Rheumatology. 1985;12(4):763-8.

6. Mirghasemi SA, Trepman E, Sadeghi MS, Rahimi N, Rashidinia S. Bone marrow edema syndrome in the foot and ankle. Foot \& Ankle International. 2016;37(12):1364-73. https://doi.org/10.1177/1071100716664783

7. Orth P, Anagnostakos K. Coagulation abnormalities in osteonecrosis and bone marrow edema syndrome. Orthopedics. 2013;36(4):290-300.

https://doi.org/10.3928/01477447-20130327-08

8. Rodriguez S, Paniagua O, Nugent KM, Phy MP. Regional transient osteoporosis of the foot and vitamin C deficiency. Clinical Rheumatology. 2007;26(6):976-8. https://doi.org/10.1007/s10067-006-0220-7

9. Horas K, Fraissler L, Maier G, Jakob F, Seefried L, Konrads C, et al. High prevalence of vitamin $D$ deficiency in patients with bone marrow edema syndrome of the foot and ankle. Foot \& Ankle International. 2017;38(7):760-6. https://doi.org/10.1177/1071100717697427

10. Hofmann S, Engel A, Neuhold A, Leder K, Kramer J, Plenk H. Bone-marrow oedema syndrome and transient osteoporosis of the hip. An MRI-controlled study of treatment by core decompression. Bone \& Joint Journal. 1993;75(2):210-6.

11. Hofmann S, Schneider W, Breitenseher M, Urban M, Plenk Jr H. "Transient osteoporosis" as a special reversible form of femur head necrosis. Der Orthopade. 2000;29(5):411-9.

12. Mayerhoefer M, Kramer J, Breitenseher M, Norden C, VakilAdli A, Hofmann S, et al. Short-term outcome of painful bone marrow oedema of the knee following oral treatment with iloprost or tramadol: results of an exploratory phase II study of 41 patients. Rheumatology. 2007;46(9):1460-5. https://doi.org/10.1093/rheumatology/kem172

13. Meizer R, Radda C, Stolz G, Kotsaris S, Petje G, Krasny C, et 
al. MRI-controlled analysis of 104 patients with painful bone marrow edema in different joint localizations treated with the prostacyclin analogue iloprost. Wiener Klinische Wochenschrift. 2005;117(7-8):278-86.

https://doi.org/10.1007/s00508-005-0326-y

14. Patel S. Primary bone marrow oedema syndromes. Rheumatology. 2013;53(5):785-92.

https://doi.org/10.1093/rheumatology/ket324

15. Bramlett KW, Killian JT, Nasca RJ, Daniel WW. Transient osteoporosis. Clinical Orthopaedics and Related Research. 1987;222:197-202. https://doi.org/10.1097/00003086-198709000-00026

16. Hastalıkları MK. Osteoporoz ve metabolik kemik hastalıkları tanı ve tedavi kılavuzu, 2016.

17. Swiglo BA, Murad MH, Schunemann HJ, Kunz R, Vigersky RA, Guyatt $\mathrm{GH}$, et al. A case for clarity, consistency, and helpfulness: state-of-the-art clinical practice guidelines in endocrinology using the grading of recommendations, assessment, development, and evaluation system. The Journal of Clinical Endocrinology \& Metabolism. 2008;93(3):666-73. https://doi.org/10.1210/jc.2007-1907

18. Atkins D, Best D, Briss PA, Eccles M, Falck-Ytter Y, Flottorp S, et al. Grading quality of evidence and strength of recommendations. BMJ (Clinical research ed). 2004;328(7454):1490-. https://doi.org/10.1136/bmj.328.7454.1490

19. Radke S, Kenn W, Eulert J. Transient bone marrow edema syndrome progressing to avascular necrosis of the hip-a case report and review of the literature. Clinical Rheumatology. 2004;23(1):83-8. https://doi.org/10.1007/s10067-003-0820-4

20. Judd DB, Kim DH, Hrutkay JM. Transient osteoporosis of the talus. Foot \& Ankle International. 2000;21(2):134-7. https://doi.org/10.1177/107110070002100207

21. Karantanas AH, Drakonaki E, Karachalios T, Korompilias AV, Malizos K. Acute non-traumatic marrow edema syndrome in the knee: MRI findings at presentation, correlation with spinal DEXA and outcome. European Journal of Radiology. 2008;67(1):22-33. https://doi.org/10.1016/j.ejrad.2008.01.053

22. Lakhanpal S, Ginsburg WW, Luthra HS, Hunder GG. Transient Regional OsteoporosisA Study of 56 Cases and Review of the Literature. Annals of Internal Medicine. 1987;106(3):444-50. https://doi.org/10.7326/0003-4819-106-3-444

23. Korompilias AV, Karantanas AH, Lykissas MG, Beris AE. Bone marrow edema syndrome. Skeletal Radiology. 2009;38(5):425-36. https://doi.org/10.1007/s00256-008-0529-1

24. Watson RM, Roach NA, Dalinka MK. Avascular necrosis and bone marrow edema syndrome. Radiologic Clinics. 2004;42(1):207-19. https://doi.org/10.1016/S0033-8389(03)00166-0

25. Berger CE, Kröner AH, Kristen K-H, Grabmeier GF, Kluger R, Minai-Pour MB, et al. Transient bone marrow edema syndrome of the knee: clinical and magnetic resonance imaging results at 5 years after core decompression. Arthroscopy. 2006;22(8):866-71.

https://doi.org/10.1016/j.arthro.2006.04.095

26. Plenk JH, Hofmann S, Eschberger J, Gstettner M, Kramer J, Schneider W, et al. Histomorphology and bone morphometry of the bone marrow edema syndrome of the hip. Clinical Orthopaedics and Related Research. 1997;334:73-84.

https://doi.org/10.1097/00003086-199701000-00010

27. Singh D, Ferrero A, Rose B, Goldberg A, Cullen N. Bone marrow edema syndrome of the foot and ankle: mid-to long-term follow-up in 18 patients. Foot \& Ankle Specialist. 2016;9(3):218-26.

https://doi.org/10.1177/1938640015609986

28. Sprinchorn AE, O'Sullivan R, Beischer AD. Transient bone marrow edema of the foot and ankle and its association with reduced systemic bone mineral density. Foot \& Ankle International. 2011;32(5):508-12. https://doi.org/10.3113/FAl.2011.0508

29. Van der Meer I, Middelkoop B, Boeke A, Lips P. Prevalence of vitamin $D$ deficiency among Turkish, Moroccan, Indian and sub-Sahara African populations in Europe and their countries of origin: an overview. Osteoporosis International. 2011;22(4):1009-21. https://doi.org/10.1007/s00198-010-1279-1

30. Alagöl F, Shihadeh Y, Boztepe H, Tanakol R, Yarman S, Azizlerli $H$, et al. Sunlight exposure and vitamin $D$ deficiency in Turkish women. Journal of Endocrinological Investigation. 2000;23(3):173-7. https://doi.org/10.1007/BF03343702

31. Atli T, Gullu S, Uysal A, Erdogan G. The prevalence of vitamin $D$ deficiency and effects of ultraviolet light on vitamin D levels in elderly Turkish population. Archives of Gerontology and Geriatrics. 2005;40(1):53-60. https://doi.org/10.1016/j.archger.2004.05.006

32. Guzel R, Kozanoglu E, Guler-Uysal F, Soyupak S, Sarpel T. Vitamin $D$ status and bone mineral density of veiled and unveiled Turkish women. Journal of Women's Health \& Gender-Based Medicine. 2001;10(8):765-70. https://doi.org/10.1089/15246090152636523

33. Hatun Ş, Ozkan B, Bereket A. Vitamin D deficiency and prevention: Turkish experience. Acta Paediatrica. 2011;100(9):1195-9. https://doi.org/10.1111/j.1651-2227.2011.02383.x

34. Duncan H, Frame B, Frost H, Arnstein AR. Regional migratory osteoporosis. Southern Medical Journal. 1969;62(1):41-4. https://doi.org/10.1097/00007611-196901000-00009

35. Gallant G, Fisher R, Sziklas J. Transient regional osteoporosis of the ankle and foot. A report of four cases and review of the literature. Orthopaedic Review. 1994;23(5):405-9.

36. Neuhold A, Hofmann S, Engel A, Leder K, Kramer J, Haller J, et al. Bone marrow edema of the hip: MR findings after core decompression. Journal of Computer Assisted Tomography. 1992;16(6):951-5. https://doi.org/10.1097/00004728-199211000-00023 